\title{
New records of forensic entomofauna in legally buried and exhumed human infants remains in Buenos Aires, Argentina
}

\author{
Roxana Mariani a, *, Rocío García-Mancuso ${ }^{\text {b }}$, Graciela L. Varela ${ }^{\text {a }}$, Ivana Kierbel a \\ a División Entomología, Facultad de Ciencias Naturales y Museo, Universidad Nacional de La Plata, Paseo del Bosque, 1900 La Plata, Buenos Aires, Argentina \\ ${ }^{\mathrm{b}}$ Cátedra de Citología, Histología y Embriología “A”, Facultad de Ciencias Médicas, Universidad Nacional de La Plata, Calle 60 y 120,1900 La Plata, Buenos \\ Aires, Argentina
}

\section{A R T I C L E I N F O}

\section{Article history:}

Received 29 May 2017

Received in revised form

15 September 2017

Accepted 18 September 2017

Available online 22 September 2017

\section{Keywords:}

Forensic entomology

Underground cadaver colonization

Forensic anthropology

Legal graves

\begin{abstract}
A B S T R A C T
The study of carrion fauna associated with buried human corpses from a forensic perspective could provide useful information in criminal investigations. Insects and other arthropods remains sampled of 44 legally exhumed infant skeletons from La Plata (Buenos Aires, Argentina). They were identified at different taxonomic levels depending on the state of preservation. The specific diversity, abundance and frequency were analyzed and each taxon was assigned to the hypothetical colonization sequence: burial colonization, post-exhumation contamination at cemetery deposit or soil fauna. The phorid Dohrniphora sp. is mentioned for the first time in Argentina as carrion fauna of underground colonization, and the assemblage of Dohrniphora sp., Megaselia scalaris and Hydrotaea aenescens is proposed as indicator of buried cadavers. These findings provide new useful data to be applied in forensic entomology research.
\end{abstract} () 2017 Elsevier Ltd and Faculty of Forensic and Legal Medicine. All rights reserved.

\section{Introduction}

Forensic entomologists collaborate in legal investigations; it studies the insects and other arthropods found in decomposing bodies and uses them to determine the moment and circumstances of death. ${ }^{1}$ This discipline considers that the corpse (from death to the skeletal stage) functions as a true ecosystem that is colonized in a predictable pattern, known as ecological succession, which can offer relevant information in criminal proceedings and trials. ${ }^{2,3}$

The colonization process has been studied mainly on aboveground outdoor and indoor animal carcasses ${ }^{2,4-6}$ but also on human bodies. ${ }^{7-11}$ The patterns of this faunal colonization may vary according to cadaver characteristics, such as size, weight, ${ }^{12}$ the presence of wounds, or environmental conditions as sun exposure, season of the year and geographical region, which also have an effect on arrival times and tenure of different insects' species. ${ }^{13-15}$

Studies of insect colonization on buried bodies has been carried out using carcasses at different depths ${ }^{16-18}$ whilst other came from exhumations of human corpses buried in soil or in coffins. ${ }^{19-22}$ Burial depth and the type of soil could influence in the

\footnotetext{
* Corresponding author.

E-mail addresses: rmariani@fcnym.unlp.edu.ar (R. Mariani),rgarciamancuso@ gmail.com (R. García-Mancuso), gracielavarela02@gmail.com (G.L. Varela), ivanakierbel@hotmail.com (I. Kierbel).
}

accessibility to the body, and the underground lower temperatures and oxygen availability produce a slower decomposition rate of bodies and reduced dispersion of decay odours; all of these could delayed the colonization and reduced the insects specific diversity that could reach the remains. ${ }^{16,20,23-25}$ Recent research carried out in field and laboratory experiments analyzed the effect of burial on the development of larvae and pupae of forensically important flies in differents type of soils and confirmed the ability of phorids, ${ }^{26}$ muscids and calliphorids ${ }^{27}$ and sarcophagids ${ }^{28}$ to colonize buried remains.

In Argentina, the first mention of necrophagous entomofauna of legal exhumations from crypts and soil was made by Oliva, ${ }^{21}$ who mentioned Hydrotaea argentina (Bigot, 1885), actually synonymy of H. aenescens (Wiedemann, 1830), Muscina sp. and Megaselia scalaris (Loew, 1866) for the city of Buenos Aires. Recently, Mariani et al. ${ }^{22}$ provided an inventory of entomofauna recovered from the skeleton of a young child and the funerary bundle belonging to a legal exhumation from the ground in the cemetery of La Plata (Buenos Aires Province), in which the muscid Hydrotaea aenescens (cited as Ophyra aenescens), was the dominant taxon. They proposed a hypothetical colonization sequence, one during the burial in soil and then a post-exhumation contamination at the cemetery deposit.

The aim of the present study was to register the occurrences of entomofauna associated to legal exhumations of human infant skeletons from Argentina and assess the taxa that can be used as 
indicators of buried cadavers in forensic cases and criminal investigations.

\section{Materials and methods}

The faunal remains analyzed in this paper were sampled from 44 exhumed skeletonized bodies of foetuses and infants up to one year old. The bodies were buried shortly after death and from individual death records from the cemetery archives it is known that inhumations happened all around the year and the bodies kept buried between 4 and 8 years. After this period of time, exhumation took place and the skeletons were stored at the cemetery deposit for relatives or the administration to decide upon their destination (Ordenanza Municipal 7638/90). After a period of time of between 2 and 7 years in the cemetery deposit, those skeletons that went unclaimed were donated by the Municipal Cemetery of La Plata (Cementerio Municipal de La Plata) to the School of Medical Sciences (Facultad de Ciencias Médicas, FCM), National University of La Plata (Universidad Nacional de La Plata, UNLP) for research and teaching purposes (Ordenanza Municipal 9471/02). The skeletons arrived at FCM in numbered plastic bags including clothing, external wrappings and sediments; they were cleaned and prepared for their inclusion in the 'Prof. Dr. Rómulo Lambre' skeletal collection housed in the FCM where they currently belong. ${ }^{29}$

\subsection{Burial conditions}

The burial location in the city of La Plata, Buenos Aires Province ( $34^{\circ} 57^{\prime} 20^{\prime \prime} \mathrm{S}, 57^{\circ} 57^{\prime} 5.96^{\prime \prime} \mathrm{W}$ ) has the humid temperate climate of the Pampas region, a mean annual precipitation of $1146 \mathrm{~mm}$, and a marked seasonality. The soil is silty and, at a depth of $50 \mathrm{~cm}$ it has an annual average temperature of $17.2^{\circ} \mathrm{C}\left(11^{\circ} \mathrm{C}\right.$ in winter and $21.4^{\circ} \mathrm{C}$ in summer). ${ }^{30}$ The inhumation occurred in the four seasons of the year and bodies were buried in the ground, sometimes clothed, placed in a soft wooden coffin (specially made for rapid decomposition) in a 40-cm-deep grave, and covered with loose soil.

\subsection{Arthropod remains}

During the process of conditioning of the skeletal material before its inclusion in the collection's storage, the fauna was sampled using brushes, pins or micro forceps, depending on the specimens' size and conditions, and the sediments were inspected through water flotation. These consisted of whole or fragmented insect adults, pupae, exuviae of larvae and other arthropods, and molluscan shells. The samples obtained were stored in labeled sealed plastic bags.

Morphological and systematic studies were undertaken at the Entomology Division (División de Entomología), School and Museum of Natural Sciences (Facultad de Ciencias Naturales y Museo, FCNyM, UNLP), where dry specimens were observed under a stereoscopic microscope (Leica EZ5). The identification was possible at the species, family or order taxonomic levels depending on the preservation of the material.

Forensically importance dipteran remains were identified by three authors (RM, GLV and IK). The characters used for the identification were based on the posterior segments, the relative position of the tubercles and features of the posterior spiracles; their shape and distance apart; the contours of the spiracular slits; the thickness, shape and completeness of the peritreme and the location of the scar and button. All these characters were diagnosed according to Queiroz and de Carvlho ${ }^{31}$; Lui and Greenberg ${ }^{32}$; Oliva $^{33,34}$; Sukontason et al. ${ }^{35}$; Barbosa Cortinhas et al. ${ }^{36}$; Grzywacz et al. ${ }^{37,}{ }^{38}$; Feng and Liu. ${ }^{39}$ Coleopterans were identified according to Almeida and Mise. ${ }^{40}$ The exemplars were compared against reference specimens of La Plata Museum collection (MLP, FCNyM, UNLP). Voucher specimens have been deposited in the collection of the MLP.

To facilitate the interpretation of the analysis of the data in the "Results" section, each exhumed skeleton was described as a "case". All of them were buried in soil inside a coffin in a particular unsheltered area of the cemetery destined to infants, and after exhumation they were placed in the cemetery deposit into numbered plastic bags that constitute their container until inclusion in Lambre collection.

The arrival, establishment and development of the entomofauna was interpreted on the basis of the location and depth of the burials, previous forensic records, and the biology of each taxon. ${ }^{22}$ A first underground colonization (burial colonization) characterized by carrion species capable of laying eggs on the remains surface and the neonated larvae reaching corpses by boring through the substrate. A second instance of colonization (post-exhumation colonization), dominated by omnivorous and storage pests that occurred in the context of the cemetery deposit and characterized by insects unable to burrow as adults or larvae. Finally, soil fauna of the burial substrate sampled with the remains is described.

The faunal attributes analyzed were: abundance, which was recorded as the number of specimens of a given taxon in the whole sample of human remains; frequency, considered as the number of occurrences of a taxon per skeleton. The association of cadaver fauna analyzed per skeleton and found in more than one case was mentioned as assemblage.

\section{Results}

A total of 1216 specimens were collected from the 44 cases. Carrion fauna known to colonize buried corpses were the most numerous $(\mathrm{n}=1025)$ and were registered in 28 cases. Other specimens were attributed to contamination at the cemetery deposit or accidental arrivals $(\mathrm{n}=49$ ), occurring in 20 cases, and in 24 cases the typical soil fauna of the burial substrate $(n=142)$ was found. Finally, cadaver fauna was found together with the fauna of the deposit in nine cases and with soil fauna in fifteen cases. The inventory of faunal remains is presented in Table 1.

\subsection{Burial insect colonization}

As regards cadaver fauna, the most abundant and frequent taxon was Megaselia scalaris (Fig. 1a), followed in importance by other fly remains of Hydrotaea aenescens (Fig. 1b), Dohrniphora sp. (Fig. 1c), and less abundant Muscina stabulans (Fallén, 1817) (Fig. 1d), and the coleopteran Ataenius sp. (Fig. 2). M. scalaris, H. aenescens and Dohrniphora sp. were found together and with a high number of specimens and also, M. scalaris and $H$. aenescens were often found together or along with less frequent taxa (M. stabulans and Ataenius sp. respectively) (Fig. 3). Some puparia were observed within other puparia; specifically, $M$. scalaris and $H$. aenescens puparia were found within puparia of their same species. Furthermore, in three cases, puparia of the above-mentioned species were also found inside bone cavities (Fig. 1e).

\subsection{Post-exhumation insect colonization}

At the cemetery deposit, the moth Tineola bisselliella (Hummel, 1823) was the most abundant and frequent insect; Tinea pellionella (Linnaeus, 1758) was the other lepidopteran recorded. Among beetles, the most abundant was Anobium punctatum (De Geer, 1774) followed by Anthrenus verbasci (Linnaeus, 1767), and Dermestes sp. In addition, cockroach oothecae (Blattodea), and remains of earwig (Anisolabididae) were found (Table 1). 
Table 1

Faunal remains recovered.

\begin{tabular}{|c|c|c|c|c|c|c|c|}
\hline Case & Order & Family & Taxa & Life stage/remains & Frequency & Abundance & Fauna \\
\hline \multirow[t]{15}{*}{ Insecta } & \multirow[t]{4}{*}{ Diptera } & \multirow[t]{2}{*}{ Muscidae } & Hydrotaea aenescens (Wiedemann) & Empty puparia & 14 & 128 & $\mathrm{CF}$ \\
\hline & & & Muscina stabulans (Fallén) & Empty puparia & 1 & 1 & $\mathrm{CF}$ \\
\hline & & \multirow[t]{2}{*}{ Phoridae } & Megaselia scalaris (Loew) & Empty puparia & 21 & 857 & $\mathrm{CF}$ \\
\hline & & & Dohrniphora sp & Empty puparia & 2 & 38 & $\mathrm{CF}$ \\
\hline & \multirow[t]{6}{*}{ Coleoptera } & Carabidae & Polpochila flaviceps (Dejean) & Adult & 1 & 1 & $\mathrm{SF}$ \\
\hline & & Silphidae & Oxelythrum erythrurum (Blanchard) & Adult & 1 & 1 & $\mathrm{SF}$ \\
\hline & & Scarabeidae & Ataenius sp & Adult fragment: head, thorax & 1 & 1 & $\mathrm{CF}$ \\
\hline & & Dermestidae & Dermestes sp & Exuviae of larvae, elytra & 2 & 2 & $\mathrm{DF}$ \\
\hline & & & Anthrenus verbasci (L.) & Exuviae of larvae, elytra & 1 & 4 & DF \\
\hline & & Anobiidae & Anobium punctatum (De Geer) & Adult fragment: head, thorax, abdomen, elytra & 8 & 8 & $\mathrm{DF}$ \\
\hline & \multirow[t]{2}{*}{ Lepidoptera } & \multirow[t]{3}{*}{ Tineidae } & Tineola bisselliella (Hummel) & Empty puparia & 15 & 29 & $\mathrm{DF}$ \\
\hline & & & Tinea pellionella (L.) & Empty puparia, adults & 1 & 1 & $\mathrm{DF}$ \\
\hline & Hymenoptera & & Solenopsis sp & Adults & 4 & 78 & $\mathrm{SF}$ \\
\hline & Dermaptera & \multirow[t]{5}{*}{ Anisolabididae } & & Adult fragment: forceps, last abdominal tergites & 1 & 1 & $\mathrm{DF}$ \\
\hline & Blattodea & & & Ooteca & 4 & 4 & DF \\
\hline \multirow[t]{3}{*}{ Myriapoda } & Scutigeromorpha & & & Adult & 1 & 1 & SF \\
\hline & Polydesmida & & & Adults & 15 & 21 & SF \\
\hline & Juliformia & & & Adults & 1 & 2 & SF \\
\hline \multirow[t]{2}{*}{ Chelicerata } & Acarii & \multirow{4}{*}{$\begin{array}{l}\text { Oribatidae } \\
\text { Gamasidae, Uropodina }\end{array}$} & & Adults & 5 & 8 & SF \\
\hline & & & & Adults & 2 & 2 & SF \\
\hline \multirow[t]{2}{*}{ Mollusca } & Gastropoda & & & Valves & 20 & 25 & SF \\
\hline & Pelecypoda & & & Valves & 3 & 3 & $\mathrm{SF}$ \\
\hline
\end{tabular}

CF, carrion fauna; DF, deposit fauna; SF, soil fauna.

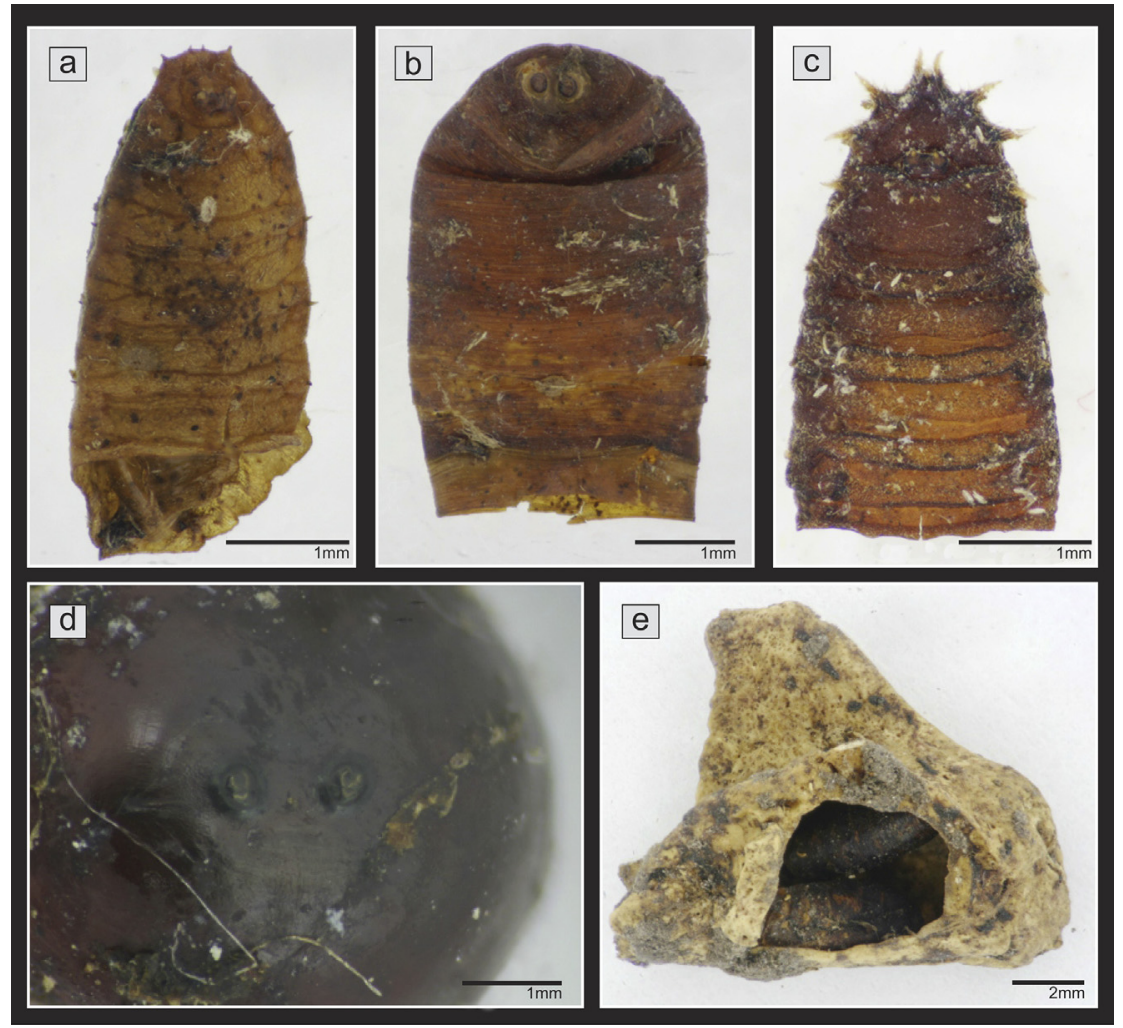

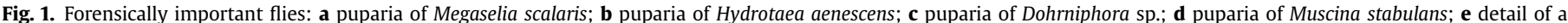
puparium inside bone cavities.

\subsection{Soil fauna}

The ants Solenopsis sp. were the most abundant, while the coleopterans were represented by Polpochila flavipes (Dejean, 1831) and Oxelytrum erythrurum (Blanchard, 1849). There were also fragments or complete adults of mites (Oribatida and Gamasida, Acari), millipedes (Polydesmidea and Juliformia) and
Scutigeromorpha centipede; mollusk bivalves of Pelecypoda and Gastropoda were present as well (Table 1).

\section{Discussion}

The cases evaluated in the present study went through the same context of burial in soil, exhumation and storage at the deposit, 


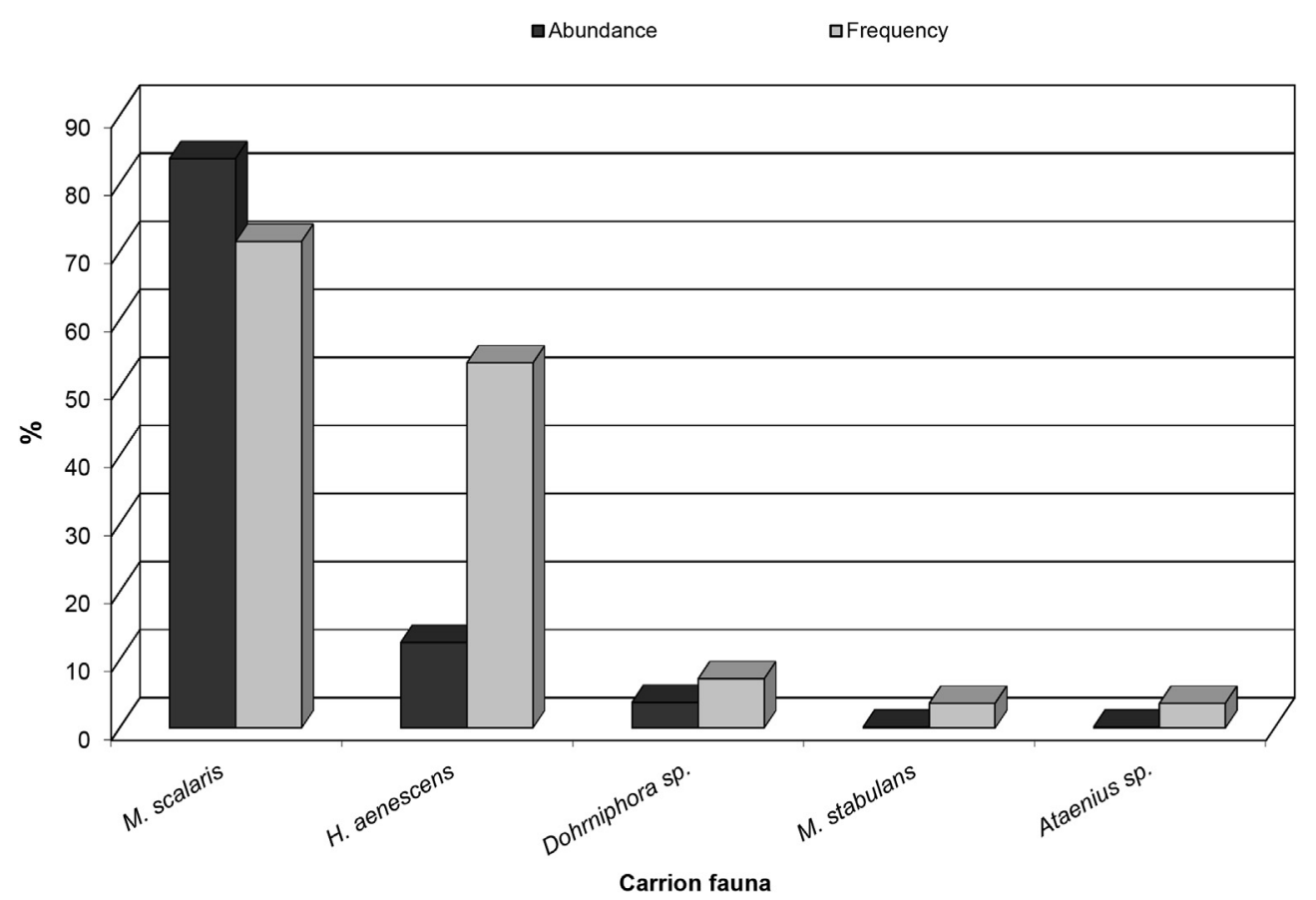

Fig. 2. Abundance and frequency of carrion fauna for the whole sample; expressed in percentages.

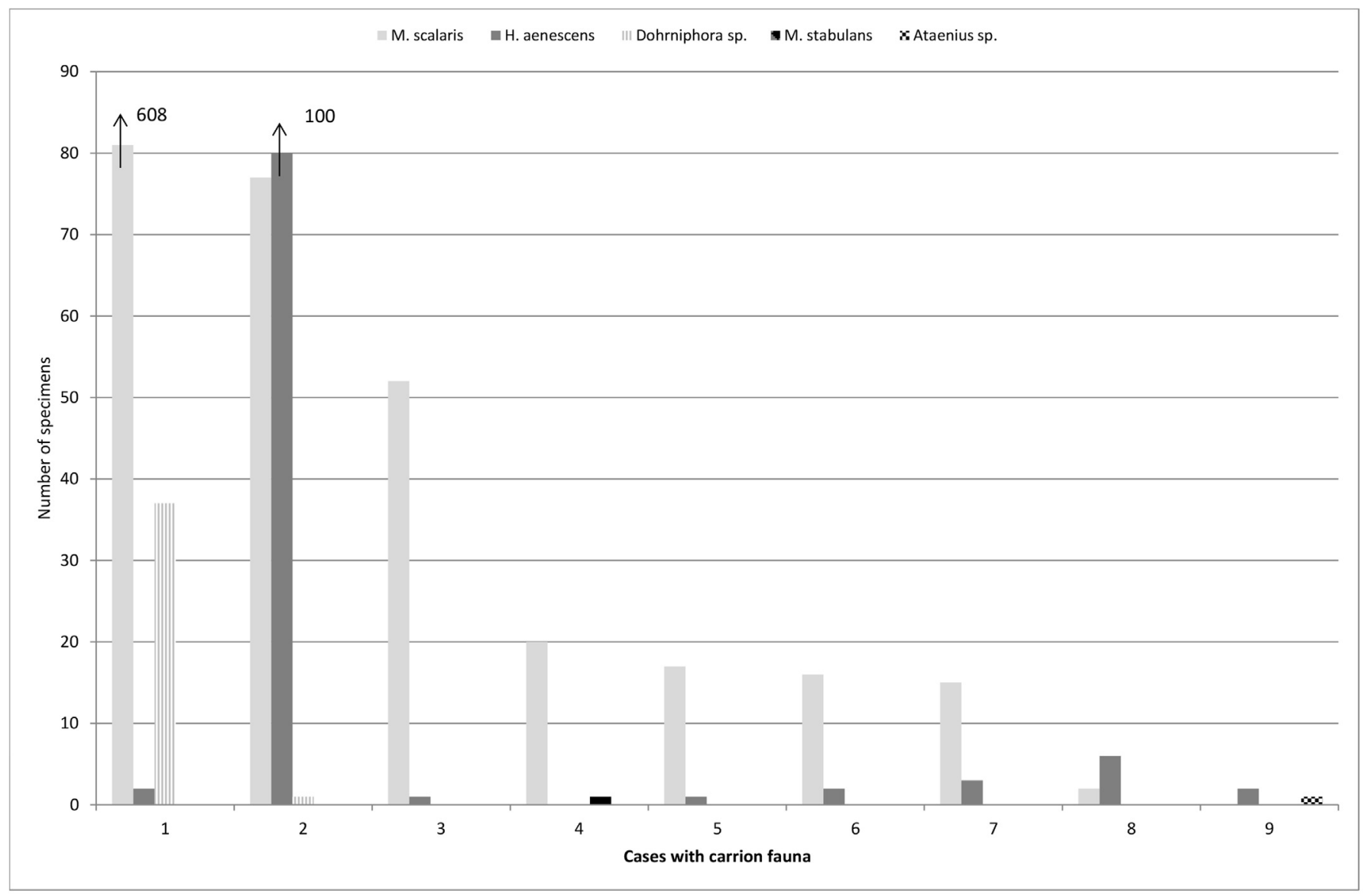

Fig. 3. Specific diversity in the cases with more than one species expressed as number of individuals. 
following contemporary burial practices and legal procedures in Argentina. Once the bodies lost all soft tissues, the exhumation took out the skeletons along with insects' remains, sediments, clothes and external wrappings when present and all these materials were placed in the cemetery deposit into numbered plastic bags.

The relevance of this contribution is based on the high number of exhumed human fetuses and infants skeletons with cadaver fauna from underground colonization, therefore, this study differs from earlier reports that analyze unique, unrepeatable criminal cases or a few exhumations from vaults and burials. ${ }^{19,21}$ The two cases with highest number of carrion fauna were buried in summer and winter, and the other 42 inhumations, that occurred in different moments of the year, were also colonizated showing that the colonization occurred independently of the season. With respect to burial colonization, despite the non methodical sampling of this study (because it is not a complete observation of the insect succession on the corpses), the predilection by primary species for certain conditions to oviposit is so marked that allowed the finding of taxa that could be interpreted as indicator of underground environment.

The genus Dohrniphora sp. is mentioned in this contribution for the first time in Argentina, confirming its forensic importance as carrion fauna as it was proposed by Disney et al. $^{41}$ for Europe. Larvae and pupae of Dohrniphora sp. had previously been sampled by the first author from exposed skeletonized human corpses in two forensic cases from Buenos Aires Province evidencing its presence in the region (unpublished data). Based on the high number of pupae collected, in this study it is also proposed that this taxon took part in the faunal succession in cadaver decomposition colonizing the buried remains. This affirmation is also supported by the reports of $D$. cornuta (Bigot, 1857) associated to buried human skeleton along with $M$. scalaris in one forensic case from Canary Islands (Spain), another place with a year-round temperate climate. $^{41}$

In the present study it is confirmed the "coffin fly" status of M. scalaris for Argentina assigned by Oliva ${ }^{21}$ because it was the most abundant species. This specie tolerates darkness; its ability to dig was experimentally proved ${ }^{26,41}$ and it was found in exhumed corpses that had been buried in wooden coffins at a depth of $30-60 \mathrm{~cm}$ in soil, ${ }^{2,42}$ and may produce extremely large populations in the absence of other insects that may arrive in earlier stages of decay. ${ }^{15}$

It is confirmed the affinity of $H$. aenescens to colonize buried corpses in Argentina because in this study it was the second species in abundance and frequency. This is in accordance with what is known for different species of the genus Hydrotaea sp. as it was observed for the species $H$. capensis (Wiedemann, 1818) in exhumed corpses from $60 \mathrm{~cm}$ depth in France ${ }^{20}$ and for $H$. aenescens in exhumations from crypts and soil in the city of Buenos Aires $^{21}$ and in a burial colonization case in the city of La Plata where it was the dominant species. ${ }^{22}$

The finding of Dohrniphora sp., M. scalaris and $H$. aenescens together and in high number of specimens in the exhumed fetuses and infants remains allows us to propose them as an indicative assemblage of underground environment. In absence of other carrion flies that arrive to exposed corpses, this assemblage could be used to infer that a body may have been buried during its whole decomposition, and could be used as evidence in criminal investigations for Argentina.

Other fauna found was the muscid M. stabulans that is able for efficient detecting and exploiting buried remains ${ }^{43}$; its occurrence along with $M$. scalaris was recorded in this study as it has been encountered in exhumed corpses buried in soil in the cities of Buenos Aires and La Plata. ${ }^{21,22}$

Another taxon that colonised the bodies in this burial context was the coleopteran Ataenius sp.; it is also proposed as part of the carrion fauna in burial context considering the fact that it has been recorded in buried carcasses at a depth of $30 \mathrm{~cm}^{44}$ and that it digs oviposition chambers and tunnels under or near exposed carcasses. $^{45}$

A post-exhumation contamination occurred at the cemetery deposit. Most of the insects that arrived in this moment are necrophagous at exposed carcasses when the tissues are completely dry; and others are omnivorous and opportunistic which colonize the bodies at any time of decay and they also behave as a stored-product pest, attracted by the wood, textiles and remains of the pioneer insects associated with the skeletons. 2,3,7,46

For example the necrophagous moths T. bisselliella and T. pellionella, ${ }^{14,22}$ and the coleopteran Dermestes sp., ${ }^{10,47,48}$ as well as the omnivorous and opportunistic feeders Blattaria and Anisolabididae are indicative of surface decomposition and do not colonize buried bodies, ${ }^{1,2,49}$ that is why they are included in the postexhumation context. The other coleopterans sampled were the carpet beetle $A$. verbasci which feeds on textiles and the xylophagous pest $A$. punctatum which feeds on the remaining fragments of wooden coffins.

Finally, the soil fauna collected from the sediments, as the predator $P$. flavipes, common in habitats with high variation in soil moisture, could be considered as evidence of the type of soil at the cemetery location. ${ }^{50}$ The other taxa found are usually associated with surface decomposition such as the necrophilous O. erythrurum, the omnivorous ants Solenopsis sp. and the detritivore Acari (i.e., Oribatida and Uropodina). The presence of some predators or omnivores such as Arachnidae, the myriapods Scutigeromorpha, Juliformia and Polydesmidea, and some small valves of Pelecypoda and Gastropoda were also indicative of the substrate where the burials took place. ${ }^{2,3}$

This contribution represents one of the few descriptions of the diversity of taxa capable of colonizing buried bodies in Argentina. Furthermore, due to the worldwide distributions of $M$. scalaris, Dohrniphora sp., M. stabulans and H. aenescens initially a New World native and actually distributed other regions, ${ }^{36,38}$ this paper offers first-hand data on faunal diversity in burial context providing information that could be used in forensic cases occurring in different countries.

\section{Conflict of interest}

There is no conflict of interest of this paper.

\section{Acknowledgements}

We like to thank R.H.L. Disney for the identification of Dorhniphora sp., and M. Dellacasa and A.C. Cicchino for the identification of the coleopterans. M. Lucía and C. Goretta for their assistance with the photography and artwork. We would also like to thank the personnel and the authorities of the Municipal Cemetery for allowing us access to this material and making its study possible. This work was supported by the Facultad de Ciencias Naturales y Museo [grant Code N/783] and Facultad de Ciencias Médicas [grant Code $\mathrm{M} / 189$ ] of the Universidad Nacional de La Plata (UNLP), Argentina.

\section{References}

1. Goff A. Estimation of postmortem interval using arthropod development and successional patterns. Forensic Sci Rev. 1993;5:81-94.

2. Smith KGV. A Manual of Forensic Entomology. London: Trustees of the British Museum (Natural History); 1986.

3. Byrd JH, Castner JL. Insects of forensic importance. In: Byrd JH, Castner JL, eds. Forensic Entomology: The Utility of Arthropods in Legal Investigations. Boca Raton: 
CRC Press; 2009:39-126. https://doi.org/10.1201/NOE0849392153.ch2.

4. Anderson G, VanLaerhoven SL. Initial studies on insect succession on carrion in Southwestern British Columbia. J Forensic Sci. 1996;44(4):617-625. https:/| doi.org/10.1520/JFS13964J.

5. Centeno N, Maldonado M, Oliva A. Seasonal patterns of arthropods occurring on sheltered and unsheltered pig carcasses in Buenos Aires Province (Argentina). Forensic Sci Int. 2002;126(1):63-70. https://doi.org/10.1016/ S0379-0738(02)00037-3.

6. Battán Horenstein M, Linhares AX. Seasonal composition and temporal succession of necrophagous and predatory beetles on pig carrion in central Argentina. Med Vet Entomol. 2011;25(4):395-401. https://doi.org/10.1111/j. 1365-2915.2011.00969.x.

7. Lefebvre F, Gaudry E. Forensic entomology: a new hypothesis for the chronological succession pattern of necrophagous insect on human corpses. Ann Soc Entomol Fr. 2009;25(3):377-392. https://doi.org/10.1080/00379271.2009. 10697622.

8. Introna F, De Donno A, Santoro V, et al. The bodies of two missing children in an enclosed underground environment. Forensic Sci Int. 2011;207(1):e40-e47. https://doi.org/10.1016/j.forsciint.2010.12.007.

9. Mariani R, Varela G, Demaría M, Rossi Batiz MF, eds. Registro de la artropodofauna cadavérica asociada a restos humanos en situaciones forenses en la provincia de Buenos Aires. CD: República Argentina: XI Congreso Nacional de Criminalística: 2010.

10. Mariani R, Varela GL, Kierbel IL, Teileche TD, eds. Insectos como testigos relevantes en la reconstrucción de un caso forense. II Congreso de Ciencias Forenses, VI Jornadas Periciales. vol. 2015. 2015.

11. Kavitha R, Nazni WA, Tan TC, Lee HL, Azirun MS. Review of forensically important entomological specimens collected from human cadavers in Malaysia (2005-2010). J Forensic Leg Med. 2013;20(5):480-482. https://doi.o $\mathrm{rg} / 10.1016 / \mathrm{j} . j f l m .2013 .03 .007$.

12. Matuszewski S, Frątczak K, Konwerski S, et al. Effect of body mass and clothing on carrion entomofauna. Int J Leg Med. 2016;130(1):221-232. https://doi.org/ 10.1007/s00414-015-1145-y.

13. Goff ML. Comparison of insect species associated with decomposing remains recovered inside dwellings and outdoors on the island of Oahu. Hawaii J Forensic Sci. 1991;36(3):748-753. https://doi.org/10.1520/JFS13085J.

14. Oliva A. Insectos de interés forense de Buenos Aires (Argentina). Primera lista ilustrada y datos bionómicos. Rev Mus Arg Cs Nat "Bernardino Rivadavia". 1997;7(2):13-59.

15. Anderson GS. Factors that influence insect succession on carrion. In: Byrd JH, Castner JL, eds. Forensic Entomology: The Utility of Arthropods in Legal Investigations. second ed. CRC Press; 2009:201-250. https://doi.org/10.1201/ NOE0849392153.

16. VanLaerhoven SL, Anderson G. Insect succession on buried carrion in two biogeoclimatic zones of British Columbia. J Forensic Sci. 1999;44(1):32-43. https://doi.org/10.1520/JFS14409J.

17. Pastula EC, Merritt RW. Insect arrival pattern and succession on buried carrion in Michigan. J Med Entomol. 2013;50(2):432-439. https://doi.org/10.1603/ ME12138.

18. Balme GR, Denning SS, Cammack JA, Watson DW. Blow flies (Diptera: Calliphoridae) survive burial: evidence of ascending vertical dispersal. Forensic Sci Int. 2012;216(1-3):e1-4. Epub 2011/09/06 https://doi.org/10.1016/j.forsciint. 2011.07.017.

19. Rodriguez WC, Bass WM. Decomposition of buried bodies and methods that may aid in their location. J Forensic Sci. 1985;30:836-852. https://doi.org/10. 1520/JFS11017J.

20. Bourel B, Tournel G, Hédouin V, Gosset D. Entomofauna of buried bodies in northern France. Int J Leg Med. 2004;118(4):215-220. https://doi.org/10.1007/ s00414-004-0449-0.

21. Oliva A. Frecuencia y distribución estacional de moscas cadavéricas (Diptera) en la Ciudad de Buenos Aires. Rev Mus Arg Cs Nat (nueva Ser). 2007:9(1):5-14.

22. Mariani R, García-Mancuso R, Varela GL, Inda AM. Entomofauna of a buried body: study of the exhumation of a human cadaver in Buenos Aires, Argentina. Forensic Sci Int. 2014;237:19-26. https://doi.org/10.1016/j.forsciint.2013.12. 029.

23. Payne JA, King EW, Beinhart G. Arthropod succession and decomposition of buried pigs. Nature. 1968;219(5159):1180-1181. https://doi.org/10.1038/ $2191180 \mathrm{a0}$

24. Singh R, Sharma S, Sharma A. Determination of post-burial interval using entomology: a review. J Forensic Leg Med. 2016;42:37-40. https://doi.org/10. 1016/j.jflm.2016.05.004.

25. Gaudry E. The insect colonisation of buried remains. In: Amendt J, Campobasso CP, Goff ML, Grassberger M, eds. Current Concepts in Forensic Entomology. London: Springer; 2010:273-311. https://doi.org/10.1007/978-14020-9684-6_13.

26. Bostock E. Megaselia Scalaris (Diptera: Phoridae), a Fly of Forensic Interest: Advances in Chronobiology and Biology. University of Huddersfield; 2015.

27. Gunn A, Bird J. The ability of the blowflies Calliphora vomitoria (Linnaeus), Calliphora vicina (Rob-Desvoidy) and Lucilia sericata (Meigen) (Diptera:
Calliphoridae) and the muscid flies Muscina stabulans (Fallén) and Muscina prolapsa (Harris) (Diptera: Muscidae) to colonise buried remains. Forensic Sci Int. 2011;207(1):198-204. https://doi.org/10.1016/j.forsciint.2010.10.008.

28. Szpila K, Voss JG, Pape T. A new dipteran forensic indicator in buried bodies. Med Vet Entomol. 2010;24(3):278-283. https://doi.org/10.1111/j.1365-2915. 2010.00883.x.

29. Salceda SA, Desántolo B, García-Mancuso R, Plischuk M, Inda AM. The 'prof. Dr Rómulo Lambre' collection: an Argentinian sample of modern skeletons. HOMO. 2012;63(4):275-281. https://doi.org/10.1016/j.jchb.2012.04.002.

30. Hurtado MA, Giménez JE, Cabral MG. Análisis ambiental del partido de La Plata: Aportes al ordenamiento territorial. Buenos Aires: Consejo Federal de Inversiones; 2006.

31. de Queiroz S, de Carvalho C. Chave pictórica e descrições de larvas de $3^{\circ}$ instar de Díptera (Calliphoridae, Muscidae e Fanniidae) em vazadouros de resíduos sólidos domésticos em Curitiba, Paraná. Ann Soc Entomol Bras. 1987;16 $165-188$.

32. Liu D, Greenberg B. Immature stages of some flies of forensic importance. Ann Entomol Soc Am. 1989;82(1):80-93. https://doi.org/10.1093/aesa/82.1.80.

33. Oliva A. Diptera (Insecta) de interés forense o causante de miasis. Claves artificiales para estadios preimaginales. In: Salomón O, ed. Actualización en artropodología sanitaria Argentina. Buenos Aires: Fundación Mundo Sano; 2002: $51-60$.

34. Oliva A. Insects of forensic interest in Buenos Aires (Argentina), addenda et corrigenda, 1. Phoridae (Diptera: Brachycera). Physis (Buenos Aires) Secc C. 2004;60:43-50.

35. Sukontason KL, Boonsriwong W, Siriwattanarungsee S, Piangjai S, Sukontason K. Morphology of puparia of Megaselia scalaris (Diptera: Phoridae) a fly species of medical and forensic importance. Parasitol Res. 2005;98(3):268. https://doi.org/10.1007/s00436-005-0052-4.

36. Barbosa Cortinhas L, Martins M, Paloma Rocha Barbosa R, de Carvalho Queiroz MM. Ultrastructure of immature stages of the black dump fly: Ophyra aenescens (Wiedemann, 1830) (Diptera: Muscidae: Azeliinae). Acta Trop. 2016;158:125-129. https://doi.org/10.1016/j.actatropica.2016.02.022.

37. Grzywacz A, Hall MJR, Pape T, Szpila K. Muscidae (Diptera) of forensic importance-an identification key to third instar larvae of the western Palaearctic region and a catalogue of the muscid carrion community. Int J Leg Med. 2017;131(3):855-866. https://doi.org/10.1007/s00414-016-1495-0.

38. Grzywacz A, Wallman JF, Piwczyński M. To be or not to be a valid genus: the systematic position of Ophyra R.-D. revised (Diptera: Muscidae). Syst Entomol. 2017;42(4):714-723. https://doi.org/10.1111/syen.12240.

39. Feng D-X, Liu G-C. Morphology of immature stages of Dohrniphora cornuta (bigot) (Diptera: Phoridae). Microsc Res Tech. 2012;75(11):1528-1533. https:// doi.org/10.1002/jemt.22096.

40. Almeida LM, Mise KM. Diagnosis and key of the main families and species of South American Coleoptera of forensic importance. Rev Bras Entomol. 2009;53: 227-244. https://doi.org/10.1590/S0085-56262009000200006.

41. Disney RHL, Garcia-Rojo A, Lindström A, Manlove JD. Further occurrences of Dohrniphora cornuta (Bigot) (Diptera, Phoridae) in forensic cases indicate likely importance of this species in future cases. Forensic Sci Int. 2014;241: e20-e22. https://doi.org/10.1016/j.forsciint.2014.05.010.

42. Campobasso CP, Disney RHL, Introna F. Case of Megaselia scalaris (loew) (Dipt., Phoridae) Breeding in a human corpse. Aggrawal's Internet J For Med Toxicol. 2004;5(1):3-5.

43. Gunn A. The colonisation of remains by the muscid flies Muscina stabulans (Fallén) and Muscina prolapsa (Harris) (Diptera: Muscidae). Forensic Sci Int. 2016;266:349-356. https://doi.org/10.1016/j.forsciint.2016.06.013.

44. Corrêa RC, Almeida LM, Moura MO. Coleoptera associated with buried carrion potential forensic importance and seasonal composition. I Med Entomol. 2014;51(5):1057-1066. https://doi.org/10.1603/ME13166.

45. Santos W, Alves A, Creão-Duarte A. Beetles (Insecta, Coleoptera) associated with pig carcasses exposed in a Caatinga area, Northeastern Brazil. Braz J Biol. 2014;74:649-655. https://doi.org/10.1590/bjb.2014.0072.

46. Nuorteva P. Sarcosaprophagous insects as forensic indicators. In: Tedeschi CG, Eckert WG, Tedeschi LG, eds. Forensic Medicine: A Study in Trauma and Environmental Hazards. New York: W. B. Saunders; 1977:1072-1095.

47. Schroeder H, Klotzbach H, Oesterhelweg L, Puschel K. Larder beetles (Coleoptera, Dermestidae) as an accelerating factor for decomposition of a human corpse. Forensic Sci Int. 2002;127(3):231-236. https://doi.org/10.1016/S03790738(02)00131-7.

48. Centeno N, Serrán M, Otero JG, Weiler N. An ancient assemblage of scavenger insects in Patagonia (Argentina). Entomol Am. 2009;115(1):77-80. https://doi.o $\mathrm{rg} / 10.1664 / 07-\mathrm{RA}-010.1$.

49. Denic N, Huyer DW, Sinal SH, Lantz PE, Smith CR, Silver MM. Cockroach: the omnivorous scavenger: potential misinterpretation of postmortem injuries. Am J Forensic Med Pathol. 1997;18(2):177-180. https://doi.org/10.1097/00000433$199706000-00014$.

50. Porrini DP, Castro AVC, Cicchino AV. Los carábidos (Coleoptera: Carabidae) asociados a los remanentes de bosque nativo en la Reserva Natural Municipal Laguna de los Padres, Buenos Aires. Rev Soc Ent Arg. 2014;73:35-48. 